\title{
The Interaction Effects of Firm Value, Managerial Ownership Retention, Earnings Forecasts and Earnings Management
}

\author{
Minwoo Lee (Corresponding Author) \\ Department of Accounting, Western Kentucky University \\ 1906 College Heights Blvd. \#11061, Bowling Green, KY 42101-1061, USA \\ Tel: 1-270-745-5001 E-mail: minwoo.lee@wku.edu
}

Hyunsoon Hwang

Kiwoom Securites Co., Ltd.

23-7 Yoido-Dong, Youngdeungpo-Gu, Seoul 150-738, Korea

Tel: 82-2-3787-5151Ｅ-mail: hyun@kiwoom.com

Received: May 16, 2012

doi:10.5430/bmr.v1n2p94
Accepted: June 7, 2012

Online Published: June 15, 2012

\begin{abstract}
This study examines the signaling and non-signaling effects of direct disclosure of expected earnings and managerial (insider) ownership in a comprehensive framework. Market valuation and cost reduction aspects of signaling are explored along with non-signaling aspects of earnings management, alignment effect, and value effect. The empirical results suggest that the market positively reacts to earnings forecast and insider ownership. These two signaling variables substitute for each other to minimize total signaling cost. The results also show that earnings forecast positively affects the extent of earnings management to reduce signaling cost, while insider ownership does not. Regarding non-signaling aspects of insider ownership, it is shown that firm value positively affects insider ownership. However, insider ownership is not found to significantly affect firm value either positively or negatively. Also, insider ownership is found to lessen the extent of earnings management only at high ownership levels.
\end{abstract}

Keywords: Simultaneous signaling, Non-signaling effects, Earnings management, Insider ownership

\section{Introduction}

\subsection{Prior Studies and Research Issues}

There exists information asymmetry between a firm and its investors: the manager of the firm has private information about the future prospects of the firm (e.g., firm value). This information asymmetry gives rise to the adverse selection problem described in Akerlof (1970) in that all firms are valued at the average firm value. This is because investors do not possess information to distinguish between high and low-value firms. Firms may provide investors with firm value information. However, since firm value is not directly verifiable, the manager with high firm value faces a problem of how to credibly signal the private information to investors, so that the firm's securities are not undervalued.

Previous literature has proposed several types of mechanisms to signal firm value. Leland and Pyle (1977) suggest, in the initial public offering setting, that entrepreneurs can signal firm value through the retention of a percentage of the firm's ownership. The entrepreneur, who is assumed to be risk-averse, prefers less ownership for a risky (i.e., uncertain as to realization of cash flow in the future) project, but is willing to retain some of that risk in order to signal the private information of the firm. They hypothesize that the better the firm value is, the larger ownership percentage the entrepreneur retains. Downs and Heinkel (1982) provide empirical support for this hypothesis.

Titman and Trueman (1986) and Datar, Feltham, and Hughes (1991) theoretically model the quality of the auditor or investment banker associated with the firm as a signal of firm value. These signals are considered credible since high quality auditors or investment bankers are more likely to uncover and disclose adverse information about the firm. Thus, a more credible auditor or investment banker provides investors with more assurance about the disclosed information about the firm. Effectively, they are employed to "certify" that the issue price is consistent with inside 
information about future prospects of the firm. This certification hypothesis was empirically supported by Krinsky and Rotenberg (1989), Menon and Williams (1991), and Feltham, Hughes, and Simunic (1991).

Signaling theory is based on two fundamental premises: market valuation relevance (i.e., the market reacts to signals) and the costs of signaling (e.g., false signaling faces substantial negative consequences). Existing studies have largely focused on the market valuation relevance of signals. Also, proposed signaling devices in past literature have been mostly limited to exogenous signaling devices such as auditor and investment banker quality. With exogenous signaling devices, firm value is indirectly implied by variables which bear no direct relationship to it.

This study focuses on two endogenous signaling devices, direct disclosure of firm value as well as managerial ownership (hereafter referred to as insider ownership). Direct disclosure is comparable to a contingent contract, such as a money-back guarantee in the product market, that induces truthful disclosure since the seller will be responsible if the actual quality turns out to be poor compared to the disclosure/advertisement. In the securities market, the manager makes a disclosure about the firm's prospects. Investors value the firm based on this disclosure. The firm is penalized (in the ways discussed in the next section), if the realized value is sufficiently low relative to the disclosure. The credibility of the disclosure is assumed to follow from its cost, i.e., the threat of penalty imposition. Hughes (1986) suggests that such contingent contracts are economically efficient because costly exogenous signals are not necessary.

There have been only a few studies that examine the cost aspect of signaling. Since signals are costly, they carry credibility and discriminate between high and low-value firms (for the low-value firm, the level of a given signal selected by the high-value firm is too costly to choose in order to mimic the high-value firm). In the context of initial public offerings, Firth (1998) finds that earnings forecasts are a major signal of firm value. Li and McConomy (2004) provide empirical support that earnings forecasts and insider ownership simultaneously signal firm value. They argue that managers choose the level of each signal based on the relative costs and benefits associated with the signals and employ the least costly combination of the multiple signals. Simultaneous signaling models of this nature are theoretically suggested by Hughes (1986) and Fan (2007).

\subsection{Purposes of study}

This paper examines signaling effects of direct disclosure of earnings forecast and insider ownership and non-signaling (value and alignment) effects revolving around insider ownership in the seasoned equity market. This study is distinguished from the existing studies on several counts. First, signaling cost aspect is incorporated with earnings management. While Li and McConomy (2004) address the optimal combination of simultaneous signals for the least signaling cost with an assumption that the signaling cost is given, the signaling cost itself can be reduced with the use of earnings management. The earnings management literature suggests that forecasting firms systematically manage earnings to move reported income towards the forecasted figure (Sohn 1994; Bugstahler \& Dichev, 1997). Therefore, the signaling cost resulting from the disclosure can be mitigated by accounting discretion exercised by the manager.

Second, this study explores related non-signaling (value and alignment) effects of insider ownership, which have not been addressed in conjunction with the signaling aspects. While a number of studies have examined the effect of insider ownership as a signal, empirically their findings may be also driven by non-signaling effects. Agency theory suggests that insider ownership is used to reduce agency costs in the firm (alignment effect, see Jensen \& Meckling, 1976; Morck, Schlifer \& Vishny, 1988). Cho (1998) and Lee and Cho (2000) empirically confirm that given firm value, the insider ownership level is determined by manager's desire to keep wealth in the firm in order to maximize manager's wealth (value effect). These two effects pertain to two non-signaling needs. However, existing studies fail to distinguish between signaling and non-signaling effects.

Finally, the effect of ownership structure on earnings management is also addressed as part of the comprehensive picture. Insider ownership has been shown to affect the extent of earnings management either positively (entrenchment effect, Al-Fayoumi, Abuzayed \& Alexander, 2010) or negatively (alignment effect, Huang, Wang, \& Zhou, 2012). However, these effects are not addressed in previous signaling studies dealing with insider ownership and earnings management.

This study intends to contribute to the signaling and earnings forecast literature by presenting a rich and comprehensive picture incorporating the issue of earnings management in the signaling context. The picture includes market valuation relevance, signaling cost, earnings management, and value, alignment, and entrenchment effects. Simultaneous signaling with earnings forecast and insider ownership can only be well understood by examining the whole picture. Therefore, providing the first comprehensive empirical evidence would enhance understanding of 
earnings forecasts, insider ownership, and earnings management. Recent corporate failures have forced investors to be wary of untruthful disclosures and potential earnings manipulation. Thus, increasing investor distrust and the paucity of research on this issue also underscore the importance of this study.

The results of this study have potential practical implications. For investigative groups (i.e., auditors, investment bankers, courts, etc.) judging whether a disclosed earnings forecast is truthful, it is essential to understand how the manager signals firm value in relation with other factors. This study regarding how disclosures are used by managers and perceived by investors provides a more reasonable basis for assessing legal liabilities of the manager or related parties like investment bankers and auditors. For investors, the implications of this study are also meaningful as investors try to estimate the true value of the firm. Given that firm value is a function of future earnings, results of the study suggest that forecasted earnings should be discounted to recognize possible manipulation.

The remainder of the paper is organized as follows. Section 2 describes a comprehensive model and presents researchable hypotheses. Sections 3 and 4 present the research methodology and empirical results, respectively. The final section summarizes the results and concludes with a discussion of limitations and future research directions.

\section{Model and Hypotheses}

\subsection{A Model of Signaling by Earnings Forecast and Earnings Management}

A model of signaling-earnings management is presented as the basis for research questions. Consider a single-period world in which a manager of a firm has a risky project that yields random earnings at the end of the period. Assume that only the manager knows the expected value of future earnings. The manager sends signals of firm value by making disclosures of firm value in the form of earnings forecast and insider ownership simultaneously.

After the forecast has been disclosed, the expected realization of future earnings is revised based on new information available to the manager. This new expectation is not disclosed again in the form of a new forecast. During the period, the manager may engage in earnings management. At the end of the period, actual earnings are realized and reported to the market. Negative consequences will occur if the forecast turns out to be inaccurate (i.e., different from reported earnings). The stages in the signaling process are as follows:

1) The manager observes firm value (i.e., the expected value of future earnings).

2) The manager sends signals of firm value using an earnings forecast and insider ownership.

3) Based on new information subsequently available to the manager, the expectation of earnings realization is revised. The manager engages in earnings management to move reported earnings toward the previous forecast. The extent of earnings management is private knowledge of the manager.

4) Actual earnings are realized and reported.

5) If the forecast proves to be ex-post inaccurate, adverse consequences will occur.

\subsection{Market Valuation Relevance}

The earnings forecast carries credibility since it is costly. The market could verify the veracity of a forecast and impose a penalty if the manager is found to have issued an inaccurate forecast. Such signaling costs are incurred both directly and indirectly. The direct costs are unfavorable market reactions if the actual earnings are higher than the forecasted figure (i.e., negative unexpected earnings). Given empirical evidence showing that stock prices positively react to unexpected earnings, negative unexpected earnings are associated with unfavorable market price reactions. Sohn (1994) shows that forecasts that prove to be ex-post in error adversely affect the market price of securities. Furthermore, firms can face litigation risk if earnings are significantly lower than the forecast. Under the current institutional environment, the forecasting firms are liable for ex-post inaccurate earnings forecasts. A stock price decline associated with a significantly inaccurate forecast may instigate lawsuits. ${ }^{1}$ In spite of current safe harbor rules, courts have staunchly maintained that forecasting firms are responsible for ex-post inaccurate forecasts even though the forecasts were made in good faith (Hughes 1986). Cao and Narayanamoorthy (2009) argue that litigation risk is one of the prime concerns that managers have in issuing earnings forecasts.

There are also indirect costs of inaccurate forecasts. Indirect costs results not only from negative unexpected earnings but from positive unexpected earnings. Even though the actual earnings turn out to be higher than the forecast, there are detrimental effects of inaccurate forecasts on the reputation of the manager. Balachandran and Sivaramakrishnan (1990) interpret the utility loss from issuing an ex-post inaccurate forecast as a loss in credibility with respect to subsequent forecasts made by the manager. Also, Alrai, Bildersee, Dontoh, and Ronen (1988) show that the market, once conditioned to the accuracy level and precise mode of a forecaster, considers the forecast accuracy in its 
interpretation of future forecasts. Recently, Graham, Harvey, and Rajgopal (2005) show that managers believe that missing an earnings target or reporting volatile earnings reduces the predictability of earnings, which creates uncertainty that investors and analysts dislike. This finding is suggestive of indirect signaling costs.

Lee (2004) finds that managers engage in income-increasing activities if actual earnings are expected to be lower than the forecast, while there are no systematic income-decreasing activities found in the opposite situation. Given this finding, one could argue that, from a non-signaling perspective, positive unexpected earnings are not a concern for managers since the market price movement is favorable. This seems to support the argument. However, that does not necessarily imply that there is no signaling cost associated with positive unexpected earnings. Even though the market reacts favorably, still there exist costs of favorably inaccurate forecast. If the former dominates the latter, Lee's finding is not necessarily supportive of the argument. Also, there is contrary evidence that managers also engage in income-decreasing earnings management. In another line of research, Rajgopal, Venkatachalam, and Jiambalvo (1999) show that $53.2 \%$ of their sample firms are found to have negative discretionary accruals.

Inaccurate forecasts damage the manager's reputation for accurately predicting future events. Since these damaging effects are of direct concern to the manager, clearly the manager has an incentive to reduce these signaling costs. In this situation as described in the model, managers have an incentive to exercise earnings management in order to manipulate (increase or decrease) reported earnings toward the forecasted figure.

These signaling costs make earnings forecast credible, and therefore the market reacts to the forecast. For insider ownership, the credibility comes from the manager's willingness to forego the benefits of diversification by retaining some ownership in the firm. The manager can hold more shares only when firm value (earnings) is higher.

As to insider ownership, based on the argument of Leland and Pyle (1977), it is also costly to hold as discussed earlier. Given their potential adverse consequences, earnings forecast and insider ownership carry credibility. Therefore, they have market valuation relevance (i.e., market reactions to the signals). Clarkson, Dontoh, Richardson, and Sefcik (1992), and Firth (1998) find that the variables have a positive impact on valuation. Thus, the following hypothesis is derived based on the above discussion:

$\mathrm{H}_{1}$ :The market positively reacts to management earnings forecast disclosure and insider ownership retention.

\subsection{Cost Aspect}

Prior research has examined the benefit aspect of signaling models by focusing on the valuation impact of signaling devices. Like Li and McConomy (2004) and Fan (2007), this study examines the cost aspect of signaling with multiple signals, earnings forecast and insider ownership. However, this study addresses the cost aspect along with the market valuation aspect within a comprehensive picture including earnings management, value effect, and alignment effect (to be discussed below).

Given that there are two signals for one attribute, the manager is likely to signal firm value in an efficient manner with the least costly combination of the signals. In equilibrium, there is trade-off between the signals, such that an increase in one signal results in a decreased need for the other signal (Hughes, 1986). This trade-off is a key empirical implication of simultaneous signaling. As noted by Li and McConomy (2004), the substitution effect cannot be inferred directly from valuation aspect studies. The trade-off between the signals suggests the following hypothesis:

$\mathrm{H}_{2}$ :The level of earnings forecast substitutes for that of insider ownership and vice versa.

Since earnings forecast and insider ownership are the signals of future earnings, the signaling costs depend on the actual earnings realization at the end of a given period. Understandably, since the market valuation is a positive function of the signals, if either signal is at its high level, the signaling cost is high. However, the signaling costs can be mitigated through manager's earnings management. This earnings management is performed in addition to substituting one signal for the other. Managers have been found to engage in earnings management to show a consistent pattern of earnings increases (Barth, Elliot, \& Finn, 1999), avoid earnings decreases or losses (Hayn 1995; Burgstahler \& Dichev, 1997), and to prevent actual earnings from deviating from their forecasts (Sohn, 1994; Lee, 1998). These studies suggest that with earnings management, the signaling costs can be mitigated.

With the use of earnings management, the manager is able to report earnings that are more consistent with the forecasted figure. Therefore, the signaling costs associated with the higher forecast figure or higher insider ownership level become less costly to the manager and therefore the manager can make greater use of these signals. The above discussion leads to the following researchable implications:

$\mathrm{H}_{3}$ :Holding other variables constant, both the levels of earnings forecast and insider ownership positively affect 
the extent of earnings management.

\subsection{Multiple Effects associated with Insider Ownership}

\subsubsection{Alignment and Value Effects}

While insider ownership can be a signal of firm value, there are other effects revolving around insider ownership. Jensen and Meckling (1976) predict that insider ownership affects firm value. They argue that the value of the firm increases as managers' stake in the firm's future earnings increases because larger managerial equity ownership helps to align the incentives of managers with those of outside shareholders, as managers bear direct wealth consequences from their decisions. This is the alignment effect. Morck et al. (1988) empirically confirm this prediction. This alignment effect must be differentiated from the signaling effect. The alignment effect pertains to the effect of insider ownership on firm value. Firm value is different from market valuation, which has to do with the signaling effect. Signaling is a process of revealing firm value to generate favorable market valuation. Although closely related to each other, the alignment effect has to be analyzed independently from the signaling effect within a comprehensive framework. This issue is first raised by Lee and Cho (2000).

The other effect to be considered is the value effect. Related to this issue is the study by Cho (1998). He raises the endogeneity issue of insider ownership, and shows that firm value determines insider ownership, not vice versa. His finding challenges the reported evidence of the alignment effect, which assumes insider ownership as an exogenous variable. Cho's finding is consistent with the argument by Demsetz and Lehn (1985) that the ownership structure is an endogenous outcome of the firm's competitive decision. Specifically, Cho shows that if firm value is higher, the manager keeps the higher portion of ownership to maximize his or her wealth. This value effect also has to be included in the analysis to distinguish it from the signaling effect.

Taken together, the findings of Cho and the results of previous studies lead to a suspicion that insider ownership and firm value may be interdependent. Therefore, the following prediction is tested for the alignment and value effects:

$\mathrm{H}_{4}$ :Insider ownership positively affects firm value, and vice versa.

\subsubsection{Alignment and Entrenchment Effects on Earning Management}

The Jensen and Meckling's (1976) argument that managerial ownership can be used to align interests between managers and owners apply to income management. Managers tend to avoid opportunistic earning management if they hold high levels of ownership (i.e., alignment effect). In this situation, the effect of insider ownership on earnings management will be negative. However, Demsetz and Lehn (1985) and Morck et al. (1988) suggest that beyond a certain ownership level, increases in ownership may allow managers to gain sufficient power to resist control exercised by owners (i.e., entrenchment effect ${ }^{2}$ ) and result in a positive effect on earnings management. There have been several studies that explore the effect of ownership structure on earnings management. The results are mixed. Choi and Seo (2008) $)^{3}$ and Huang et al. (2012) report a negative effect, while Al-Fayoumi et al. (2010) show a positive effect. Depending on which effect dominates, the sign of the direction will be determined. Therefore, this issue is purely an empirical question. Thus, no hypothesis is presented.

\subsubsection{Comprehensive Picture}

Management earnings forecast and insider ownership can be used as firm value signals. However, a number of relating effects revolve around the two signals (i.e., signaling, earnings management, alignment, and value effects). Therefore, it is necessary to separate the signaling effect from other effects. This separation can be done only within a comprehensive framework of analysis. Since these effects occur simultaneously, any individual effect can be analyzed within the framework (comprehensive picture).

Figure 1 depicts the effects to be studied in this research. The figure shows signaling-related links such as the signaling, the substitution effect and earnings management for cost reduction and non-signaling value, alignment, and entrenchment effects by showing directions of causality.

\section{Data}

\subsection{Sample Selection and Earning Forecasts Data}

The sample initially consists of 628 earnings forecasts that were randomly selected from the Dow Jones News Retrieval Service for the period of 2005 to 2008. To be included in the sample, forecasts should be attributed to corporate officials, and they should be point estimates (rather than range estimates). Among those, 305 observations are eliminated because they lack sufficient information needed to compute firm value or estimate earnings management or have incomplete data on stock prices, or insider ownership. As a result, the final sample contains 323 
firms. For descriptive statistics of the data used in this study, Table 1 provides summary statistics of the sample firms.

\subsection{Measurement of Key Variables}

Stock prices represent the market valuation. The stock price data of forecasting firms are obtained from the CRSP tapes. The insider ownership variable is proxied by the percentage of voting stock owned by the company's officers and directors. The ownership information is obtained from Compact Disclosure, The Value Line Investment Survey, Standard and Poor's Corporation Records, and proxy statements. The measure of firm value is Tobin's Q, which is defined as the ratio of market value of the firm compared to replacement cost of assets. ${ }^{4}$ The Tobin's Q measure is computed by the algorithm proposed by Lindenberg and Ross (1981).

\subsection{Measure of Earnings Management}

Earnings management can be achieved in various ways such as through the use of accruals, changes in accounting methods, and changes in capital structure. The ideal research design would enable the researcher to observe the set of feasible accounting choices available to managers in order to assess whether their ultimate decisions resulted in higher or lower income than would otherwise have been reported. Since the earnings figure that would have been reported without manipulation is not directly observable, a surrogate variable for the extent of income manipulation should be developed.

A number of models for detecting earnings management have been proposed. Dechow, Sloan, and Sweeney (1995) evaluate the performance of early models and conclude that the Jones (1991) model as modified by them exhibits significant improvement over the early models as to power of detecting earnings management. This modified Jones model has been widely used to date (e.g., Huang et al., 2012) in the relevant literature. However, the model is criticized for misspecification for firm-periods experiencing nonrandom performance.

Kothary, Leone, and Wasley (2005) propose a performance- and industry-matching approach between the sample and non-sample firms. This method greatly improves model specification and power over the traditional discretionary accrual approaches including the modified Jones model. More recently, Stubben (2010) and Dechow, Hutton, Kim, and Sloan (2012) note that the performance matching procedures suffer a substantial loss in power, especially in detecting expense manipulation. They propose a revenue-based model and approach that incorporates accrual reversals, respectively. These models are shown to be significantly superior to the model of Kothary et al. in terms of test power and specification.

Given that the sample firms in this study are not initial public offering or seasoned equity offering firms, ones that is subject to accounting-related SEC enforcement actions, etc., there is no reason to believe that the sample of this study is a nonrandom one experiencing nonrandom (extreme) performance. The modified Jones model performs well with nonrandom samples. ${ }^{5}$

The data collected for this study do not include those for a potential control group (non-forecasting firms) making matching, suggested by Kothary et al. (2005), not feasible. Also, it is noted that the improved models by Stubben (2010) and Dechow et al. (2012) are proposed only very recently. ${ }^{6}$ Given the prevalence of the modified Jones model (Dechow et al., 1995), its appropriateness for this study, and other issues noted above, this study uses the model to estimate the discretionary accrual as the proxy for earnings management.

The discretionary accrual is defined as the estimated error term of the following regression:

$\mathrm{TA}_{\mathrm{jt}} / \mathrm{A}_{\mathrm{jt}-1}=\alpha_{\mathrm{j}}\left[1 / \mathrm{A}_{\mathrm{t}-1}\right]+\beta_{1 \mathrm{j}}\left[\left(\Delta \mathrm{RV}_{\mathrm{t}}-\Delta \mathrm{REC}_{\mathrm{t}}\right) / \mathrm{A}_{\mathrm{t}-1}\right]+\beta_{2 \mathrm{j}}\left[\mathrm{PPE} \mathrm{jt}_{\mathrm{t}} / \mathrm{A}_{\mathrm{jt}-1}\right]+\varepsilon_{\mathrm{jt}}$

where:

$T A_{j t}=$ total accrual in year $\mathrm{t}$ for firm $\mathrm{j}$ measured as $\left[\Delta\right.$ Current Assets $_{\mathrm{jt}}-\Delta$ Cash $_{\mathrm{jt}}-\Delta$ Current Liabilities $_{\mathrm{jt}}$

- Depreciation and Amortization Expense ${ }_{\mathrm{j} t}$ ] for changes from year $\mathrm{t}-1$ to $\mathrm{t}$ or year $\mathrm{t}$ for firm $\mathrm{j}$;

$A_{j t-1}=$ total assets in year $\mathrm{t}-1$ for firm $\mathrm{j}$;

$\Delta R V_{j t}=$ revenues in year $\mathrm{t}$ less revenues in year $\mathrm{t}-1$ for firm $\mathrm{j}$;

$\triangle R E C_{t}=$ net receivable in year $\mathrm{t}$ less net receivable in year $\mathrm{t}-1$ for firm $\mathrm{j}$;

$P P E_{j t}=$ gross amount of property, plant, and equipment in year $\mathrm{t}$ for firm $\mathrm{j}$;

$\varepsilon_{j t}=$ error term in year $\mathrm{t}$ for firm $\mathrm{j}$ (interpreted as discretionary accruals);

$t=1,2, \ldots, \mathrm{T}_{\mathrm{j}} \quad\left(\mathrm{T}_{\mathrm{j}}\right.$ is the last year of time-series of available data), and;

$\Delta=$ Change. 
For each firm, the model is estimated using the longest time series of available annual data. Firms that have less than nine observations are deleted from the analysis. The summary statistics of $\alpha_{j}, \beta_{1 j}$, and $\beta_{2 j}$ are reported in Table 2. As expected, the average estimated coefficient of property, plant and equipment is negative. The property, plant, and equipment term is related to an income-decreasing non-discretionary accrual (i.e., depreciation expense). The average estimated coefficient of change in revenue, net of change in accounts receivable, is not as obvious.

The test of the hypothesis is performed using estimated errors of the above equation, $\mathrm{e}_{\mathrm{j} t \mathrm{t}}$. The following procedures are employed for each firm. First, the estimated error for the forecast disclosure year $(t=F), e_{j F}$ is computed. Also, an estimated standard deviation, $\mathrm{s}\left(\mathrm{e}_{\mathrm{j}} \mathrm{t}\right)$, is calculated using the time-series $\mathrm{t}=1, \ldots, \mathrm{T}_{\mathrm{j}}$, and the estimated error is scaled by the estimated standard deviation to obtain the following standardized error:

$\mathrm{V}_{\mathrm{jF}}=\mathrm{e}_{\mathrm{j} F} / \mathrm{s}\left(\mathrm{e}_{\mathrm{jt}}\right)$

A positive (negative) standardized error, $\mathrm{V}_{\mathrm{jF}}$, implies that firm $\mathrm{j}$ uses accruals to increase (decrease) reported earnings of year $\mathrm{F}$ for which an earnings forecast has been previously disclosed.

\section{Empirical Specification and Results}

\subsection{Simultaneous Equation Regression Analysis}

As discussed in Section 2 and shown in Figure 1, there are possible mutual effects among the variables. For example, insider ownership is not exogenously given. It can be a function, as well as, a determinant of firm value. To address this interdependency (endogeneity or simultaneity) issues, a simultaneous equation system is used for analysis. The simultaneous equation system also makes it possible for this study to address efficient signaling by examining the substitution effect between the two firm value signals.

An ordinary regression setup would treat "independent" variables as exogenously given. To the extent that the independent variable is endogenously determined, the ordinary regression yields biased and inconsistent coefficients and the observed relation may be spurious. In addressing the direction of causality, the simultaneous equation approach takes interdependency into consideration. This procedure makes it possible to avoid a false attribution of causality and misinterpretation of the relation between the variables of interest.

The simultaneous equation system analyzes possible reciprocal relationships among insider ownership, earnings forecast, market valuation, and firm value. The equation system is similar to the one used by Cho (1998) and Lee and Cho (2000). Table 3 summarizes the hypotheses to be tested under the simultaneous equation system (equation 3 below) and the predicted effects. It also includes non-hypothesized effects. To test the hypotheses and explore other effects, the following simultaneous equation system is estimated based on the two-stage least squares (2SLS) method:

$$
\begin{aligned}
& \mathrm{MV}_{\mathrm{j}}=\mathrm{f}_{1}(\mathrm{FCT}, \mathrm{OWN}, \text { AUD }) \\
& \mathrm{FCT}_{\mathrm{j}}=\mathrm{f}_{2}(\mathrm{Q}, \mathrm{OWN}, \mathrm{ACC}, \text { VOL }) \\
& \mathrm{OWN}_{\mathrm{j}}=\mathrm{f}_{3}(\mathrm{Q}, \mathrm{FCT}, \text { VOL, LIQ }) \\
& \mathrm{ACC}_{\mathrm{j}}=\mathrm{f}_{4}(\mathrm{OWN}, \mathrm{FCT}, \text { VOL, LEV , AUD }) \\
& \mathrm{Q}_{\mathrm{j}}=\mathrm{f}_{5}(\mathrm{OWN}, \text { LEV , ASS })
\end{aligned}
$$

where for firm $\mathrm{j}$,

$$
\begin{aligned}
& \mathrm{MV}=\text { market price (per share) of stock on the earnings forecast date } \\
& \mathrm{FCT}=\text { management earnings forecast in terms of earnings per share } \\
& \mathrm{OWN}=\text { insider ownership percentage } \\
& \mathrm{Q}=\text { Tobin's } \mathrm{Q} \\
& \mathrm{ACC}=\text { earnings management measured by discretionary accrual, } \mathrm{V}_{\mathrm{F}} \text { in equation } 2 . \\
& \mathrm{AUD}=\text { auditor quality (Big Four }=1 \text {; Non-Big Four }=0 \text { ) } \\
& \mathrm{VOL}=\text { standard deviation of changes in profit rate, where profit rate is profit before extraordinary items / } \\
& \text { replacement cost of assets } \\
& \text { LIQ }=\text { cash flow (after-tax income }+ \text { amortization) / replacement cost of assets } \\
& \text { LEV }=\text { financial leverage ratio computed as debts / assets } \\
& \text { ASS = logarithm of replacement cost of assets }
\end{aligned}
$$


The equation system also includes several variables to control possible effects on the dependent variables. In the market valuation $\left(f_{1}\right)$ and earnings management $\left(f_{4}\right)$ equations, AUD (auditor quality) is included. Regarding $f_{1}$, since high-quality (Big Four) auditors provide more assurance to accounting numbers of client firms, the market reacts more favorably to firms associated with these auditors (Datar et al., 1991; Feltham et al., 1991). There have been several studies reporting that high-quality auditors increase deterrence of income management (Becker, Defond, Jiambalvo, \& Subramanyam, 1988; Kanagaretnam, Lim \& Lobo, 2010). To control the effect, AUD is included in $\mathrm{f}_{4}$.

VOL (volatility) is included in the forecast $\left(f_{2}\right)$, ownership $\left(f_{3}\right)$ and earnings management $\left(f_{4}\right)$ equations. In $f_{2}$, it controls for the effect that managers tend to understate the forecast if the earnings volatility is high (risky). In $f_{3}$, it controls for the possibility that high firm-specific uncertainty affects the level of insider ownership either positively (for monitoring) or negatively (risk-aversion). ${ }^{7}$ In $\mathrm{f}_{4}$, VOL controls the documented tendency of firms to strategically issue earnings forecasts (Cao \& Narayanamoorthy, 2009) or manage earnings to lessen signaling costs (Lee, 2004).

ACC (discretionary accrual) is included in $\mathrm{f}_{2}$, since earnings management to a greater extent naturally leads to higher earnings forecast. LIQ (liquidity) is included in $\mathrm{f}_{3}$, since high liquidity allows managers to use internal funds and thus affects insider ownership stake. In $\mathrm{f}_{4}$, LEV (financial leverage ratio) is included as a control for the tendency of firms to manage earnings to loosen debt covenant constraints (DeFond \& Jiambalvo, 1994). In $\mathrm{f}_{5}$ also, LEV serves as an instrument to control for the possibility that financial leverage affects firm value (McConnell \& Servaes, 1995). ASS (assets) is included also in $\mathrm{f}_{5}$ to control for a potential size effect. ${ }^{8}$ Unobservable intangible assets affect firm value. The ASS variable, which may be correlated with intangible assets (Morck et al., 1988), serves to control for the above effect.

\subsection{Non-Monotonicity Issue and Piecewise Specification of Insider Ownership}

There are some studies that report the effect of insider ownership may not be monotonic. Stultz (1988) argues that insider ownership positively affects firm value at low levels but, due to the entrenchment effect, the effect of insider ownership becomes negative at fairly high levels. That is because managers obtain enough power to resist monitoring and control by owners and make decisions to maximize their own benefits at the expense of stockholders (Fama \& Jensen, 1983; Gibbs, 1993). Morck et al. (1988) further argue that additional increase in ownership will cause reconvergence of interests because as managers hold greater levels of ownership, they effectively become owners and act in the best interest of owners. These non-monotonic effects are empirically supported by Morck et al. and McConnell and Servaes (1995). Also, ownership structure may affect the extent of earnings management differentially. In another line of research, Koh (2003), among others, finds that institutional ownership ${ }^{9}$ affects earnings management positively at low ownership levels and negatively at high levels.

Given potential non-monotonic effects of insider ownership, the simultaneous equation model uses a piecewise specification when insider ownership is entered as an independent variable. This piecewise regression is useful when different effects of an independent variable are expected in different ranges. Insider ownership is entered as three separate variables for three ownership ranges. Considering the argument of Mork et al. (1988), three ranges are used rather than simple high and low ranges in many studies. Based on the model by Cho (1998) and Lee and Cho (2000), the following three insider ownership variables are defined using $5 \%$ and $25 \%$ as break points determining the three ranges.

$\begin{aligned} \text { OWN1 }= & \alpha, \text { if } \alpha \leq 5 \\ & 5, \text { if } \alpha>5 \\ \text { OWN2 }= & 0, \text { if } \alpha \leq 5 \\ & \alpha-5, \text { if } 5<\alpha \leq 25 \\ \text { OWN3 }= & 0, \text { if } \alpha \leq 25 \\ & \alpha-25, \text { if } \alpha>25\end{aligned}$

where, $\alpha=$ insider ownership (OWN)

The rationale for $5 \%$ and $25 \%$ breakpoints is provided by Morck et al. (1988). 5\% represents a focal stake beyond which ownership is no longer negligible and is a point of mandatory public disclosure of ownership required by the Securities and Exchange Commission. $25 \%$ is considered as the ownership level beyond which a hostile bid for the firm cannot succeed.

\subsection{Results}

The results of the simultaneous equation regression analysis are shown in Table 4. In interpreting the regression results, an estimated coefficient is considered strongly significant if the associated $p$-value is less than or equal to $5 \%$. The $10 \%$ significant level is associated with a weakly significant effect of the variable in question. This weak 
significance level is interpreted as no effect unless there is some additional evidence. The interpretational issue arises especially with the piecewise insider ownership variable. If the effect of insider ownership is strongly significant in one range and weakly significant in another range, it is interpreted to be sufficiently significant to confirm the effect or hypothesis in question.

\subsubsection{Market Valuation}

In the first column of the table, the results of the market value regression $\left(f_{1}\right)$ are presented. The results show that both management earnings forecast and insider ownership have positive effects on market valuation. The effect of earnings forecast is significant at the $5 \%$ level. The insider ownership variable is shown to positively affect market valuation at low and middle ranges (OWN1, OWN2). Although positive, the effect becomes insignificant in the high range. These results generally confirm the signaling effects of the two variables. Thus, hypothesis 1 is supported. These results are consistent with those reported by Clarkson et al. (1992). The confirmed signaling effects indicate that the two variables have market value relevance.

In equations $\mathrm{f}_{2}$ and $\mathrm{f}_{3}$, it is confirmed that firm value $(\mathrm{Q})$ also significantly affects earnings forecast and insider ownership. This suggests with other things constant firms with higher values issue more favorable earnings predictions and hold a higher level of insider ownership, which in turn result in greater market valuation.

\subsubsection{Substitution Effect}

The substitution effect between the two signaling variables is confirmed in the columns for equations $\mathrm{f}_{2}$ and $\mathrm{f}_{3}$. As expected, in $\mathrm{f}_{2}$, insider ownership is shown to have a negative effect on the earnings forecast disclosure at the $5 \%$ level in the low range and $10 \%$ in the middle range of ownership, although insignificantly positive in the high range. Also, in $f_{3}$, the effect of the forecast variable is shown to be significantly negative at the $5 \%$ level. Thus, it is confirmed that there is tradeoff between insider ownership and management earnings forecast as two competing variables simultaneously used for firm value in a signaling cost-minimizing manner. Thus hypothesis 2 is generally confirmed. This result is consistent with those reported by Li and McConomy (2004).

\subsubsection{Earnings Management}

The effects of management earnings forecast and insider ownership on the magnitude of earnings management are reported in the $f_{4}$ column. The earnings forecast variable is shown to have a significantly positive effect at the $5 \%$ level. This suggests that the higher the earnings forecast is, to the greater extent managers exercise earnings management to mitigate signaling costs. Chaney and Lewis (1995) provide explanations regarding this result.

The effect of insider ownership is insignificant in low and middle ranges. Only in the high range, it is significantly negative. Therefore, hypothesis 3 is partly supported only for the effect of earnings forecast. As discussed, there are also other non-signaling effects of insider ownership on earnings management. Therefore, this particular result is interpreted later along with other effects.

\subsubsection{Value and Alignment Effects}

The reciprocal relationships between insider ownership and firm value are observed in equations $f_{3}$ and $f_{5}$. In the insider ownership regression $\left(f_{3}\right)$, Tobin's $Q$ is shown to be an important determinant of insider ownership. The coefficient of Q is positive at the 5\% level. The results suggest that managers in firms with higher firm value hold a larger fraction of shares. In the firm value regression $\left(\mathrm{f}_{5}\right)$, the positive effect of insider ownership on firm value is weakly significant only in the middle range and insignificant elsewhere. Therefore, it is confirmed that firm value determines insider ownership, but not vice versa. Thus, hypothesis 4 is partly supported. Consistent with Demsetz and Lehn (1985) and Cho (1998), the results show that insider ownership is endogenously determined by firm value and it is not an exogenous factor of firm value.

\subsubsection{Alignment or Entrenchment Effect on Earnings Management}

The estimated coefficient of OWN in $\mathrm{f}_{4}$ shows combined effects of insider ownership, signaling cost reduction, alignment, and entrenchment effects on earnings management. While the signaling and entrenchment effects predict a positive coefficient, the alignment effect is associated with a negative sign. The resulting coefficient depends on which effect dominates. The estimated coefficient is insignificantly positive in low and middle ranges and significantly negative in the high range. Therefore, signaling cost reduction and entrenchment effects are not supported while the alignment effect is confirmed only at high levels of insider ownership. The results do not necessarily suggest that the signaling cost reduction or entrenchment effects are not present. They may have been partially offset by the alignment effect. However, it can be confirmed that the alignment effect is dominantly present at high insider ownership levels, suggesting that insider ownership, at its high levels, can mitigate managers' 
opportunistic earnings management behavior. In section 4.4, the issues revolving around insider ownership are revisited.

\subsubsection{Other Non-Hypothesized Effects}

In $\mathrm{f}_{2}$, the effect of ACC (earnings management) on earnings forecast is shown to be significantly positive. Also the results show firm value significantly affects earnings forecast in a positive manner. These two effects are observed as expected. In the simultaneous equation analysis, the effects of the control variables are also examined. In equation $\mathrm{f}_{1}$, the effect of AUD (audit quality) on market valuation is positive. However, its effect is only weakly significant. Therefore, the effect of the auditor quality is not confirmed. The effects of VOL (volatility) in equations $\mathrm{f}_{2}$ and $\mathrm{f}_{4}$ are significant at $10 \%$. Thus, only weak support is given to the arguments that volatility affects management earnings forecast and that firms manage earnings to a greater extent when volatility is greater.

Among other control variables, only LEV (financial leverage) in equation $\mathrm{f}_{4}$ and ASS (assets) in equation $\mathrm{f}_{5}$ are shown to have some significant effects. The results suggest that financial leverage only weakly affects the extent of earnings management. However, assets have a strong positive effect on firm value. Other control variables, VOL (volatility) and LIQ (liquidity) in equation $\mathrm{f}_{3}$ and LEV (financial leverage) in equation $\mathrm{f}_{5}$, are all shown to have insignificant effects.

\subsection{Alternative Testing Approaches for Robustness Check}

The reported results do not confirm the signaling cost reduction effect of insider ownership in equation $\mathrm{f}_{4}$. Regarding the influence on earnings management in the same equation, while the alignment effect is confirmed in the high range of insider ownership, the entrenchment effect is not supported. It should be noted that the coefficient of insider ownership can also represent non-signaling alignment and entrenchment effects. Furthermore, in equation $\mathrm{f}_{5}$, the effect of insider ownership on firm value is not confirmed. Given that there are several effects revolving around insider ownership, further analysis is desirable to better interpret the results. It is also desirable to ensure that reported results are not changed depending on the research methodology employed. Additional tests are performed with an alternative model specification, different set of breakpoints, division of the sample according to growth opportunity, and exclusion of outliers.

\subsubsection{Alternative Model Specifications}

Following the majority of studies, insider ownership is included in the regressions as a single variable. The assumption associated with this specification is that the effect of insider ownership on other variables is uniform regardless of the level of ownership. Table 5 reports the results of this robustness test. Given that the focus of further analysis is on insider ownership as a determinant of earnings management and firm value, the results are reported for those effects only. The results on market valuation relevance $\left(f_{1}\right)$, substitution effects $\left(f_{2}\right)$, cost reduction effect of earnings forecast $\left(f_{3}\right)$ and value effect $\left(f_{3}\right)$ are confirmed again and they are qualitatively equivalent to those in Table 4.

The top panel of Table 5 shows the effect of insider ownership as the determinant of earnings management. The results under piecewise specification 1 are the reproduction of the original results in Table 4, and they are provided for comparison purposes. Under non-piecewise specification, it is shown to have no significant effect. The results with the original specification suggest that in both low and middle ranges, insider ownership has no significant effect with significantly negative effect present only in the high range.

In the bottom panel, the effect of insider ownership on firm value is reported. The non-piecewise specification shows that its effect is not significant. The reported effect with the new piecewise specification is also similar to that with the original specification in that, generally, there is no significant effect present to affect firm value.

Overall, the reported results are sufficiently robust, which indicate that they are not sensitive to model specifications. The comparison between piecewise and non-piecewise specifications enables one to infer advantages of using the piecewise specification. In both equations, OWN (non-piecewise) shows no significant effect. However, piecewise specifications can detect some significant effects in some ranges.

\subsubsection{Different Breakpoints}

To examine a possible effect of different breakpoints on the outcome, a different set of breakpoints is used to redefine the three ownership variables. As noted, the results in table 4 are based on breakpoints of $5 \%$ and $25 \%$. Since there are no established rules in choosing the breakpoints, this study also use the statistical grid search technique employed by Cho (1998). ${ }^{10}$ Following the method, two breakpoints of $9 \%$ and $37 \%$ are identified.

With the new breakpoints, the results on market valuation relevance $\left(f_{1}\right)$, substitution effects $\left(f_{2}\right)$, cost reduction effect 
of earnings forecast $\left(f_{3}\right)$ and value effect $\left(f_{3}\right)$ are confirmed once again and they are qualitatively equivalent to those in Table 4. The results relating to equations $\mathrm{f}_{4}$ and $\mathrm{f}_{5}$ are shown in Table 5 under piecewise specification 2 . The new results are qualitatively similar in that the signs and significance levels of relevant coefficients are comparable between the original and alternative piecewise models. It is reconfirmed that the signaling cost reduction and non-signaling entrenchment effects are not present and the non-signaling alignment effect operates only at the high ownership range.

\subsubsection{Different Growth Opportunities and Outlier Effect}

An examination is performed on the possibility that the simultaneous regression results are sensitive to different effects of debt on firm value with different growth opportunities. McConnell and Servaes (1995) find that firm value is negatively (positively) related to debt for high (low) growth firms. For exploring this possibility, sample firms are divided into two groups and the simultaneous equation regression is estimated for each group. ${ }^{11}$ The regression estimates for all variables remain qualitatively similar to those reported in Tables 4 and 5. Therefore, the results are not reported.

Finally, the analysis is performed with 57 firms excluded that belong to the top 5\% in any categories among market value, earnings forecast, insider ownership, earnings management, and firm value measures. The regression results are qualitatively similar again, suggesting that there is no influence of the potential outliers on the inferences from the simultaneous regression analysis.

Taken together, all of the above robustness tests confirm the validity of the reported results in that they are not sensitive to the research methodology used.

\section{Discussion and Conclusion}

\subsection{Summary and Discussion}

Financial market signaling is a process of revealing manager's private information about firm value to the market. Since signals are costly to use, they carry credibility. Therefore, the market reacts favorably in valuing securities with good signals. The manager of a firm can signal firm value by using direct disclosure of expected earnings and insider ownership retention simultaneously. This study examines the signaling effect of these two variables in two aspects: market valuation and signaling cost. Based on a comprehensive framework, both signaling and non-signaling effects (value, alignment, and entrenchment effects) are examined at the same time. Previous studies have not distinguished the signaling and non-signaling aspects.

The empirical results suggest that the market positively reacts to earnings forecast disclosure and insider ownership (signaling effect). Also, it is shown that earnings forecast substitutes for insider ownership (substitution effect). The study also finds that earnings forecast positively affects the extent of earnings management to reduce signaling cost (signaling cost aspect), while insider ownership does not. In addition, the results show that insider ownership also possesses non-signaling effect in that firm value positively affects insider ownership (value effect).

However, insider ownership is not found to significantly affect firm value either positively or negatively. Also, insider ownership is found to lessen the extent of earnings management only at high ownership levels (alignment effect). The reported results are sufficiently robust in that they are not qualitatively changed depending on the methodology employed.

It is not clear whether insider ownership affects firm value. Agency theory suggests that an increase in ownership either more closely aligns the interests of the manager and shareholders to positively affect firm value or makes managers entrenched to decrease firm value. In related studies, the empirical results are mixed. The alignment and entrenchment effects are reported by Morck et al. (1988) and Lee and Cho (2000) for initial public offering firms. For seasoned firms, Cho's (1998) findings suggest that the effect of insider ownership predicted by agency theory does not exist. There is no a priori reason to believe that agency problems are resolved for initial public offering firms through insider ownership, but not for seasoned firms. It could be conjectured that the extent of information asymmetry is different for seasoned and IPO firms and that might affect the results. This issue could be rigorously addressed in future research.

\subsection{Limitations and Possible Future Extensions}

Some limitations on research methodology should be noted for future improvement. Future extensions of this research may address the following issues. It is suggested that forecasting firms systematically engage in earnings management in order to move reported income towards the forecasted figure. Managers will engage in earnings management to report earnings close to the previous forecast, if actual income is expected to be lower than the 
forecast (bad news). In this situation, signaling costs are reduced by earnings management. However, when actual earnings are expected to exceed the previous forecast (good news), it is of interest to investigate if managers will systematically decrease earnings towards the forecasted value in order to reduce indirect signaling costs as discussed in section 2. Empirical evidence is mixed in this regard. Even if managers do not engage in earnings management in this situation, the observed effects are the combined effects of favorable market price reactions and negative impact on the manager's perceived ability to provide accurate forecasts. If they are not properly separated, the result is inconclusive in this situation. The asymmetrical situations may require the division of the sample into two groups, good news and bad news categories. For each group, the implications of accruals (earnings management) to other variables can be examined separately. Possibly, the effects of accruals on earnings forecasts and insider ownership are different for different groups.

As to the measurement of earnings management, this study uses the modified Jones model. Several studies propose improved earnings management detection models in terms of specification and power especially for nonrandom samples. Given that the sample in this study can be considered random, the model used in this study works sufficiently well. However, new approaches such as Kothary et al. (2005), Stubben (2010), and Dechow et al. (2012) are generally considered to have considerably improved the estimation of earnings management and therefore can be employed in future extensions of this study. It is of interest to find whether any of the above mentioned earnings management proxy can significantly affect the reported results of this study.

Also, in this study industry effects are not considered. Kothary et al. (2005)'s earnings management measure also require matching on industry. The inclusion of industry variable would control for industry effects on the interrelationships among these variables. With the inclusion of an industry variable, future research would better explore the relationships among the variables examined in this study.

\section{References}

Akerlof, G. (1970). The market for lemons: quality uncertainty and the market mechanism. Quarterly Journal of Economics 89, 488-500.

Al-Fayoumi, N., Abuzayed, B., \& Alexander, D. (2010). Ownership structure and earnings management in emerging markets: The case of Jordan. International Research Journal of Finance and Economics, 38, 28-47. Retrieved from http://www.eurojournals.com/finance.htm

Alrai, Z., Bildersee, J., Dontoh, A., \& Ronen, I. (1988). Market response to managerial forecasts: The impact of past managerial forecast accuracy and precision. Working Paper, New York University.

Balachandran, B., \& Sivaramakrishan, K. (1990). Management earnings forecasts: A theoretic framework. Working Paper, Northwestern University.

Barth, M., Elliot, J., \& Finn, M. (1999). Market rewards associated with patterns of increasing earnings. Journal of Accounting Research, 37, 387-413.

Becker, C. Defond, M., Jiambalvo, J. \& Subramanyam, K. (1988). The effect of audit quality on earnings management. Contemporary Accounting Research, 15, 1-24.

Bugstahler, D., \& Dichev, I. (1997). Earnings management to avoid earnings decreases and losses. Journal of Accounting and Economics, 24, 99-126. http://dx.doi.org/10.1016/S0165-4101(97)00017-7

Cao, Z. \& Narayanamoorthy, G.S. (2009). The effect of litigation risk on management earnings forecasts. Working Paper. Universities of Washington Tacoma and Illinois at Urbana-Champaign.

Chaney, P.K, \& Lewis, C.M. (1995). Earnings management and firm valuation under asymmetric information. Journal of Corporate Finance, 1, 319-345.

Cho, M. H. (1998). Ownership structure, investment, and corporate value: an empirical analysis. Journal of Financial Economics, 47, 103-121.

Choi, S.K, \& Seo, J.W. (2008). Institutional ownership and accounting transparency. Asia-Pacific Journal of Financial Studies, 37, 627-673.

Clarkson, P, Dontoh, A., Richardson, G., \& Sefcik, S. (1992). The voluntary inclusion of earnings forecasts in IPO prospectuses. Contemporary Accounting Research, 8, 601-626.

Datar, S., Fe1 tham, G. \& Hughes, J. (1991). The role of audits and audit quality in valuing new issues. Journal of Accounting and Economics, 14, 3-49. http://dx.doi.org/10.1016/0167-7187(91)90057-R 
Dechow, P., Sloan, R., \& Sweeney, A. (1995). Detecting earnings management. The Accounting Review, 70, 193-225. , Hutton, AP., Kim, J.H. \& Sloan, R.G. (2012). Detecting earnings management: A new approach, Journal of Accounting Research, 50, 275-334. 10.1111/j.1475-679X.2012.00449.x

Defond, M., \& Jiambalvo, J. (1994). Debt covenant violation and manipulation of accruals. Journal of Accounting and Economics, 17, 145-176. http://dx.doi.org/10.1016/0165-4101(94)90008-6

Demsetz, H., \& Lehn, K. (1985). The structure of corporate ownership: Causes and consequences. Journal of Political Economy, 93, 1155-1177.

Downs, D. \& Heinkel, R. (1982). Signaling and valuation of unseasoned new issues. The Journal of Finance, 37, $1-10$.

Fama, E.F., \& Jensen, M. (1983). Separation of ownership and control. Journal of Law and Economics, 26, 301-315.

Fan, Q. (2007). Earnings management and ownership retention for initial public offering firms: Theory and evidence. The Accounting Review, 82, 27-64.

Feltham, G., Hughes, J. \& Simunic, D. (1991). Empirical assessment of the impact of auditor quality on valuation. Journal of Accounting and Economics, 14, 375-399. http://dx.doi.org/10.1016/0165-4101(91)90009-D

Firth, M. (1998). IPO profit forecasts and their role in signaling firm value and explaining post-listing returns. Applied Financial Economics, 8, 29-39.

Gibbs, P.A. (1993). Determinants of corporate restructuring: The relative importance of corporate governance, takeover threat, and free cash flow. Strategic Management Journal, 14, 51-68.

Graham, J.R., Harvey, C.R., \& Rajgopal, S. (2005). The economic implications of corporate financial reporting, Working Paper. Duke University, National Bureau of Economic Research, \& University of Washington.

Hayn, C. (1995). The information content of losses. Journal of Accounting and Economics, 20, 125-123. http://dx.doi.org/10.1016/0165-4101(95)00397-2

Huang, H., Wang, W., \& Zhou, J. (2012). Shareholders rights, insider ownership and earnings management, Forthcoming in Abacus.

Hughes, P. (1986). Signaling by direct disclosure under asymmetric information. Journal of Accounting and Economics, 8, 119-142. http://dx.doi.org/10.1016/0165-4101(86)90014-5

Jensen, M., \& Meckling, W. (1976). The theory of firm: managerial behavior, agency costs and ownership structure. Journal of Financial Economics, 3, 305-360. http://dx.doi.org/10.1016/0304-405X(76)90026-X

Jones, J. (1991). Earnings management during import relief investigation. Journal of Accounting Research, 29, 193-228.

Kanagaretnam, K., Lim, C.Y., \& Lobo, G. J. (2010). Auditor Reputation and earnings management: International evidence from the banking industry. Journal of Banking and Finance, 34, 2318-2327.

King, T.H.D., \& Wen, M.M. (2011). Shareholder governance, bondholder governance, and managerial risk taking. Journal of Banking and Finance, 35, 512-531.

Koh, P.S. (2003). On the association between institutional ownership and aggressive corporate earnings management in Australia. The British Accounting Review, 35, 105-128.

Kothari, S. P., Leone, A., \& Wasley. C. (2005). Performance-matched discretionary accrual measures. Journal of Accounting and Economics, 39, 163-97. http://dx.doi.org/10.1016/j.jacceco.2004.11.002

Krinsky, I. \& Rotenberg, W. (1989). The valuation of initial public offerings. Contemporary Accounting Research, 5, 501-515.

Lee, M., (1998). Managers' discretion on earnings manipulation and characteristics of forecasting firms. Journal of Accounting and Finance Research, 5, 32-47.

, \& Cho, M. H. (2000). Firm value, inside ownership, and investment for initial public offering firms. Journal of Accounting and Finance Research, 7, 79-92.

, (2004). Determinants of earnings management subsequent to reputation signaling, Journal of Accounting and Finance Research, 12, 68-84.

Leland, H., \& Pyle, D. (1977). Information asymmetries, financial structure, and financial intermediation. The 
Journal of Finance, 32, 371-387.

Li, Y. \& McConomy, B. (2004). Simultaneous signaling in IPOs via managerial earnings forecasts and retained ownership: An empirical analysis. Journal of Accounting, Auditing, and Finance, 19, 1-28.

Lindenberg, E., \& Ross, S. (1981). Tobin's Q ratio and industrial organization. Journal of Business, 54, 1-32.

McConnell, J., \& Servaes, H. (1995). Equity ownership and two faces of debt. Journal of Financial Economics, 39, 131-157.

McLaughlin, R., Ruback, R. \& Tehranian, H. (1996). Does corporate quality matter? Working Paper. Boston College.

Menon, K., \& Williams, D. (1991). Auditor credibility and initial public offerings. The Accounting Review, 66, 313-332.

Morck, R., Schleifer, A. \& Vishny, R. (1988). Management ownership and market valuation: An empirical analysis. Journal of Financial Economics, 20, 293-315. http://dx.doi.org/10.1016/0304-405X(88)90048-7

Rajgopal, S., Venkatachalam, M., \& Jiambalvo, J. (1999). Is institutional ownership associated with earnings management and the extent to which stock prices reflect future earnings? Working Paper. University of Washington and Stanford University. http://dx.doi.org/10.2139/ssrn.163433

Sohn, S. (1994). Managers' discretion after management earnings forecasts and characteristics of forecasting firms. Yonsei Business Review, 31, 177-198.

Stubben, S. R. (2010). Discretionary revenues as a measure of earnings management. The Accounting Review, 85, 695-717. 10.2308/accr.2010.85.2.695

Stulz, R. (1988). Managerial control of voting rights: Financing policies and the market for corporate control. Journal of Financial Economics, 20, 25-54. http://dx.doi.org/10.1016/0304-405X(88)90039-6

Titman, S. \& Trueman, B. (1986). Information quality and the valuation of new issues. Journal of Accounting and Economics, 8, 159-172. http://dx.doi.org/10.1016/0165-4101(86)90016-9

\section{Notes}

Note 1. Hughes (1986) examines litigation risk associated with signaling firm value in the context of initial public offerings. Similar risk is also faced by seasoned firms which forecast future earnings.

Note 2. Entrenchment originally pertains to the effect of managerial ownership on firm value (see section 4.2). At high insider ownership levels, an increase in insider ownership makes management more entrenched and less subject to owners' control or the discipline of the market, causing firm value to be reduced. With respect to earnings management, the same terms, alignment and entrenchment effects, are used also. Given that earnings management is not desirable from an owners' standpoint, any force that decreases (increases) earnings management is termed alignment (entrenchment) effect.

Note 3. This studies deals with the effect of institutional ownership on earnings management (manager's opportunistic behavior). However, the effects of insider and institutional ownership are comparable in that both ownerships try to curb manager's opportunistic behavior. The higher institutional ownership is, the greater control the institution will exercise on the manager to protect its interest (alignment). In some situation, institutions and the manager have common interests. In that case, the higher institutional ownership is, the worse the manager's misbehavior will be to the value of the firm (entrenchment). These arguments are explained by King and Wen (2011).

Note 4. Tobin's Q may proxy for other things such as corporate quality or corporate opportunities (McLaughlin, Ruback, \& Tehranian, 1996).

Note 5. The sample consists of the firms that issue earnings forecasts. Given the large proportion of forecasting firms, either they constitute a nonrandom sample or their effect of non-randomness would be limited.

Note 6. These articles are published after the data collection phase of this study.

Note 7. Cho (1998) suggests that as volatility increases, insider ownership level may increase because the uncertainty makes it difficult to monitor the contribution of managers to firm performance. On the other hand, volatility may add to managerial risk-aversion, causing managers to avoid higher ownership.

Note 8. The replacement cost of assets is used as the proxy for size in Morck et al. (1988) and McConnell and Servaes (1990). In this study, the replacement cost of assets is the denominator of the dependent variable, Tobin's Q. The replacement cost measured with error will create a spurious relationship between firm value and size (Cho, 
1998). Therefore, the logarithm of the replacement cost is used as the measure of firm size.

Note 9. Refer to Note 3 above.

Note 10. See Cho (1998) for detailed procedures. His assistance in the grid search computations for this study is greatly appreciated.

Note 11. Consistent with the method by McConnell and Servaes (1995), the grouping is performed based on price-to-operating earnings $(\mathrm{P} / \mathrm{E})$ ratio. A firm is considered to have a high growth opportunity, if the $\mathrm{P} / \mathrm{E}$ ratio is high.

Table 1. Descriptive statistics for sample firms

\begin{tabular}{lcrr}
\hline \multicolumn{1}{c}{ Variable $^{\mathrm{a}}$} & $\underline{\text { Mean }}$ & $\underline{\text { Std. dev. }}$ & $\frac{\text { Median }}{5.032}$ \\
Market value of stock $^{\mathrm{a}}$ & 4.538 & 7.958 & 0.085 \\
Management earnings forecast $^{\mathrm{b}}$ & 0.060 & 0.092 & 0.072 \\
Insider ownership $^{\mathrm{c}}$ & 0.129 & 0.218 & 5.381 \\
Firm value $^{\mathrm{d}}$ & 6.715 & 12.879 & 0.023 \\
Earnings management $^{\mathrm{e}}$ & 0.015 & 0.037 & 1.000 \\
Auditor quality $^{\mathrm{f}}$ & 0.792 & 0.183 & 0.021 \\
Volatility $^{\mathrm{g}}$ & 0.019 & 0.003 & 0.116 \\
Liquidity $^{\mathrm{h}}$ & 0.131 & 0.196 & 0.185 \\
Leverage $^{\mathrm{i}}$ & 0.215 & 0.174 & \\
\hline
\end{tabular}

This table presents summary statistics of the sample firms.

${ }^{a}$ Market value of stock is total market price of stock on the day of earnings forecast, stated in billions.

${ }^{\mathrm{b}}$ Management earnings forecast is earnings forecast figure scaled by the total market value of stock.

${ }^{\mathrm{c}}$ Insider ownership is percent of stock ownership by members of the board of directors.

${ }^{\mathrm{d}}$ Firm value is measured by Tobin's Q x Replacement cost of assets in billions.

${ }^{\mathrm{e}}$ Earnings management is measures by the magnitude of discretionary accrual computed based on equation 1 .

${ }^{\mathrm{f}}$ Auditor quality is a dichotomous variable, 1 for Big Four and 0 for Non-Big Four auditor.

${ }^{g}$ Volatility is risk or uncertainty in stock return, measure by standard deviation of changes in profit rate.

${ }^{\mathrm{h}}$ Liquidity is cash flows (after-tax income + amortization) divided by replacement cost of assets.

${ }^{i}$ Leverage is financial leverage ratio computed as debts divided by replacement cost of assets.

Table 2. Descriptive statistics for regression equation coefficients ${ }^{\mathrm{a}}$ of the modified Jones model

\begin{tabular}{|c|c|c|c|c|c|c|c|}
\hline Variable & Mean & $\underline{\text { Std Dev }}$ & $\underline{\text { Median }}$ & $\underline{\text { Min }}$ & Quartile 1 & Quartile 3 & $\underline{\text { Max }}$ \\
\hline Constant & 2.103 & 12.456 & 0.412 & -13.533 & -0.452 & 5.248 & 38.631 \\
\hline$t$-stat. & 0.224 & 0.992 & 0.234 & -2.784 & -0.416 & 1.005 & 3.426 \\
\hline$\triangle \mathrm{RV}-\Delta \mathrm{REC}$ & 0.315 & 0.162 & 0.273 & -0.624 & 0.012 & 0.202 & 1.246 \\
\hline$t$-stat. & 1.615 & 1.763 & 1.425 & -2.283 & 0.248 & 2.173 & 9.032 \\
\hline PPE & -0.083 & 0.203 & -0.259 & -0.683 & -0.173 & -0.042 & 0.482 \\
\hline$t$-stat. & -1.761 & 1.992 & -1.509 & -3.389 & -0.480 & -0.309 & 1.990 \\
\hline $\mathrm{n}$ & 13.70 & 1.520 & 12 & 10 & 13 & 15 & 14 \\
\hline $\operatorname{Adj} R^{2}$ & 0.261 & 0.291 & 0.298 & 0.098 & 0.193 & 0.538 & 0.781 \\
\hline
\end{tabular}

${ }^{a}$ Statistics shown here are those of the estimated coefficients, $\alpha_{\mathrm{j}} \mathrm{s}, \beta_{1 \mathrm{j}} \mathrm{s}$, and $\beta_{2 \mathrm{j}} \mathrm{s}$ in the equation below (equation 1). Variables are defined in section 3.3.

$\mathrm{TA}_{\mathrm{jt}} / \mathrm{A}_{\mathrm{jt}-1}=\alpha_{\mathrm{j}}\left[1 / \mathrm{A}_{\mathrm{t}-1}\right]+\beta_{1 \mathrm{j}}\left[\left(\Delta \mathrm{RV}_{\mathrm{t}}-\Delta \mathrm{REC}_{\mathrm{t}}\right) / \mathrm{A}_{\mathrm{t}-1}\right]+\beta_{2 \mathrm{j}}\left[\mathrm{PPE}_{\mathrm{jt}} / \mathrm{A}_{\mathrm{jt}-1}\right]+\varepsilon_{\mathrm{jt}}$ 
Table 3. Hypotheses and predicted effects in the simultaneous equation system

\begin{tabular}{|c|c|c|c|c|c|}
\hline Hypothesis & Effects to be examined & $\underline{\text { Eqn. }}$ & Dep. Variable & $\underline{\text { Indep. Variable }}$ & $\begin{array}{l}\text { Predicted } \\
\underline{\text { Sign }}\end{array}$ \\
\hline $\mathrm{H}_{1}$ & Signaling, Market Valuation & $\mathrm{f}_{1}$ & MV & $\begin{array}{l}\text { FCT } \\
\text { OWN }\end{array}$ & $\begin{array}{l}+ \\
+\end{array}$ \\
\hline $\mathrm{H}_{2}$ & Signaling Cost, Substitution & $\begin{array}{l}f_{2} \\
f_{3}\end{array}$ & $\begin{array}{l}\text { FCT } \\
\text { OWN }\end{array}$ & $\begin{array}{l}\text { OWN } \\
\text { FCT }\end{array}$ & $\begin{array}{l}- \\
-\end{array}$ \\
\hline $\mathrm{H}_{3}$ & Signaling Cost, Cost Reduction & $\mathrm{f}_{4}$ & $\mathrm{ACC}$ & $\begin{array}{l}\text { FCT } \\
\text { OWN }\end{array}$ & $\begin{array}{l}+ \\
+\end{array}$ \\
\hline $\mathrm{H}_{4}$ & $\begin{array}{l}\text { Non-signaling, Firm Value } \\
\text { Value Effect } \\
\text { Alignment Effect }\end{array}$ & $\begin{array}{l}f_{3} \\
f_{5}\end{array}$ & $\begin{array}{l}\text { OWN } \\
\text { Q }\end{array}$ & $\begin{array}{c}\text { Q } \\
\text { OWN }\end{array}$ & $\begin{array}{l}+ \\
+\end{array}$ \\
\hline n.a. & $\begin{array}{l}\text { Non-signaling, Firm Value } \\
\text { Entrenchment Effect }\end{array}$ & $\mathrm{f}_{5}$ & OWN & Q & - \\
\hline & $\begin{array}{l}\text { Non-signaling, Earnings Management } \\
\text { Alignment Effect } \\
\text { Entrenchment Effect }\end{array}$ & $\begin{array}{l}f_{4} \\
f_{4}\end{array}$ & $\begin{array}{l}\mathrm{ACC} \\
\mathrm{ACC}\end{array}$ & $\begin{array}{l}\text { OWN } \\
\text { OWN }\end{array}$ & $\begin{array}{l}- \\
+\end{array}$ \\
\hline
\end{tabular}


Table 4. Results of simultaneous equation analysis

\section{Equation (Dependent Variable)}

\begin{tabular}{|c|c|c|c|c|c|}
\hline Independent Variable & $f_{l} \underline{(M V)}$ & $f_{2} \underline{(F C T)}$ & $f_{3} \underline{(O W N)}$ & $f_{4} \underline{(A C C)}$ & $f_{5}(Q)$ \\
\hline $\begin{array}{l}\text { FCT } \\
\text { (earnings forecast) }\end{array}$ & $\begin{array}{l}7.256 \\
(2.127)^{* *}\end{array}$ & & ${ }^{-0.672}$ & $\begin{array}{l}0.075 \\
(2.011)^{* *}\end{array}$ & \\
\hline $\begin{array}{l}\text { OWN1 } \\
\text { (insider ownership) }\end{array}$ & $\begin{array}{c}1.619 \\
(2.292)^{* *}\end{array}$ & $\begin{array}{l}-1.903 \\
(-2.108)^{* *}\end{array}$ & & $\begin{array}{l}0.120 \\
(0.983)\end{array}$ & $\begin{array}{c}1.793 \\
(1.158)\end{array}$ \\
\hline $\begin{array}{l}\text { OWN2 } \\
\text { (insider ownership) }\end{array}$ & ${ }^{1.732}{ }^{* .062)^{* *}}$ & $\begin{array}{l}-2.302 \\
(-1.787)^{*}\end{array}$ & & $\begin{array}{c}0.058 \\
(1.347)\end{array}$ & $\begin{array}{l}1.380 \\
(1.734)^{*}\end{array}$ \\
\hline $\begin{array}{l}\text { OWN3 } \\
\text { (insider ownership) }\end{array}$ & $\begin{array}{r}2.801 \\
(1.263)\end{array}$ & $\begin{array}{l}-3.038 \\
(-1.427)\end{array}$ & & $\begin{array}{l}-0.108 \\
(1.983)^{* *}\end{array}$ & $\begin{array}{c}2.375 \\
(1.293)\end{array}$ \\
\hline $\begin{array}{l}\text { Q } \\
\text { (Tobin's Q) }\end{array}$ & & $\begin{array}{l}0.095 \\
(3.073)^{* * *}\end{array}$ & $\begin{array}{l}0.283 \\
(2.171)^{* *}\end{array}$ & & \\
\hline $\begin{array}{l}\text { ACC } \\
\text { (discretionary accrual) }\end{array}$ & & $\begin{array}{l}6.325 \\
(2.012)^{* *}\end{array}$ & & & \\
\hline $\begin{array}{l}\text { AUD } \\
\text { (auditor dummy) }\end{array}$ & $\begin{array}{r}0.025 \\
(1.571)^{*}\end{array}$ & & & $\begin{array}{c}-0.002 \\
(-1.002)\end{array}$ & \\
\hline $\begin{array}{l}\text { VOL } \\
\text { (volatility, risk) }\end{array}$ & & $\begin{array}{c}-7.812 \\
(-1.698)^{*}\end{array}$ & $\begin{array}{c}-0.003 \\
(-1.143)\end{array}$ & $\begin{array}{l}1.518 \\
(1.697)^{*}\end{array}$ & \\
\hline $\begin{array}{l}\text { LIQ } \\
\text { (liquidity) }\end{array}$ & & & $\begin{array}{c}0.093 \\
(1.312)\end{array}$ & & \\
\hline $\begin{array}{l}\text { LEV } \\
\text { (financial leverage) }\end{array}$ & & & & $\begin{array}{c}0.027 \\
(1.812)^{*}\end{array}$ & $\begin{array}{c}1.470 \\
(0.869)\end{array}$ \\
\hline $\begin{array}{l}\text { ASS } \\
\text { (assets, size) }\end{array}$ & & & & & $\begin{array}{l}0.023 \\
(2.127)^{* *}\end{array}$ \\
\hline $\operatorname{Adj} R^{2}$ & .086 & .092 & .071 & .067 & .064 \\
\hline
\end{tabular}

$(\mathrm{n}=323)$

The results are based on the simultaneous equation system (equation 3). The equation and the variables are as shown in section 4.1 .

$t$-statistics are in parentheses.

${ }^{* * * * * *},{ }^{* *}$, and ${ }^{*}$ indicate significance at the 1,5 , and $10 \%$ levels, respectively. 
Table 5. Further analysis on signaling cost reduction and non-signaling effects of insider ownership

\begin{tabular}{|c|c|c|c|c|}
\hline \multicolumn{5}{|c|}{ Equation (Dependent Variable): $f_{4}(A C C)$} \\
\hline & & \multicolumn{3}{|c|}{ Insider Ownership Specification } \\
\hline Prediction & $\begin{array}{l}\text { Independent } \\
\text { Variable }\end{array}$ & $\begin{array}{l}\text { Non-piecewise } \\
\text { Specification }\end{array}$ & $\begin{array}{c}\text { Piecewise } \\
\text { Specification } 1^{\mathrm{a}}\end{array}$ & $\begin{array}{c}\text { Piecewise } \\
{\text { Specification } 2^{\mathrm{b}}}\end{array}$ \\
\hline $\begin{array}{l}\text { Signaling cost reduction } \\
\text { effect }(+)\end{array}$ & OWN & $\begin{array}{c}0.097 \\
(0.983)\end{array}$ & & \\
\hline \multirow[t]{5}{*}{$\begin{array}{l}\text { Alignment effect }(-) \\
\text { Entrenchment effect }(+)\end{array}$} & OWN1 & & $\begin{array}{l}0.120 \\
(0.983)\end{array}$ & $\begin{array}{c}0.163 \\
(1.274)\end{array}$ \\
\hline & OWN2 & & $\begin{array}{c}0.058 \\
(1.347)\end{array}$ & $\begin{array}{c}0.036 \\
(0.891)\end{array}$ \\
\hline & OWN3 & & $\begin{array}{l}-0.108 \\
(1.983)^{* *}\end{array}$ & $\begin{array}{l}-0.127 \\
(2.162)^{* *}\end{array}$ \\
\hline & \multicolumn{4}{|c|}{ Equation (Dependent Variable): $f_{5}$ (Tobin's $Q$ ) } \\
\hline & & \multicolumn{3}{|c|}{ Insider Ownership Specification } \\
\hline Prediction & $\begin{array}{l}\text { Independent } \\
\text { Variable }\end{array}$ & $\begin{array}{l}\text { Non-piecewise } \\
\text { Specification }\end{array}$ & $\begin{array}{c}\text { Piecewise } \\
\text { Specification } 1^{\mathrm{a}}\end{array}$ & $\begin{array}{c}\text { Piecewise } \\
\text { Specification } 2^{\mathrm{b}}\end{array}$ \\
\hline \multirow{4}{*}{$\begin{array}{l}\text { Alignment effect }(+) \\
\text { Entrenchment effect }(-)\end{array}$} & OWN & $\begin{array}{c}1.869 \\
(1.125)\end{array}$ & & \\
\hline & OWN1 & & $\begin{array}{c}1.793 \\
(1.158)\end{array}$ & $\begin{array}{l}2.185 \\
(0.928)\end{array}$ \\
\hline & OWN2 & & $\begin{array}{l}1.380 \\
(1.734)^{*}\end{array}$ & $\begin{array}{c}1.231 \\
(1.379)\end{array}$ \\
\hline & OWN3 & & $\begin{array}{l}2.375 \\
(1.293)\end{array}$ & $\begin{array}{c}3.270 \\
(1.698)^{*}\end{array}$ \\
\hline
\end{tabular}

\footnotetext{
The results are based on the simultaneous equation system (equation 3). The equation and the variables are as shown in section 4.1 .

a uses $5 \%$ and $25 \%$ as breakpoints, reproduced from Table 4 .

${ }^{\mathrm{b}}$ uses $9 \%$ and $37 \%$ as breakpoints.

$(\mathrm{n}=323)$

$t$-statistics are in parentheses.

${ }^{* * *},{ }^{* *}$, and ${ }^{*}$ indicate significance at the 1,5 , and $10 \%$ levels, respectively.
} 


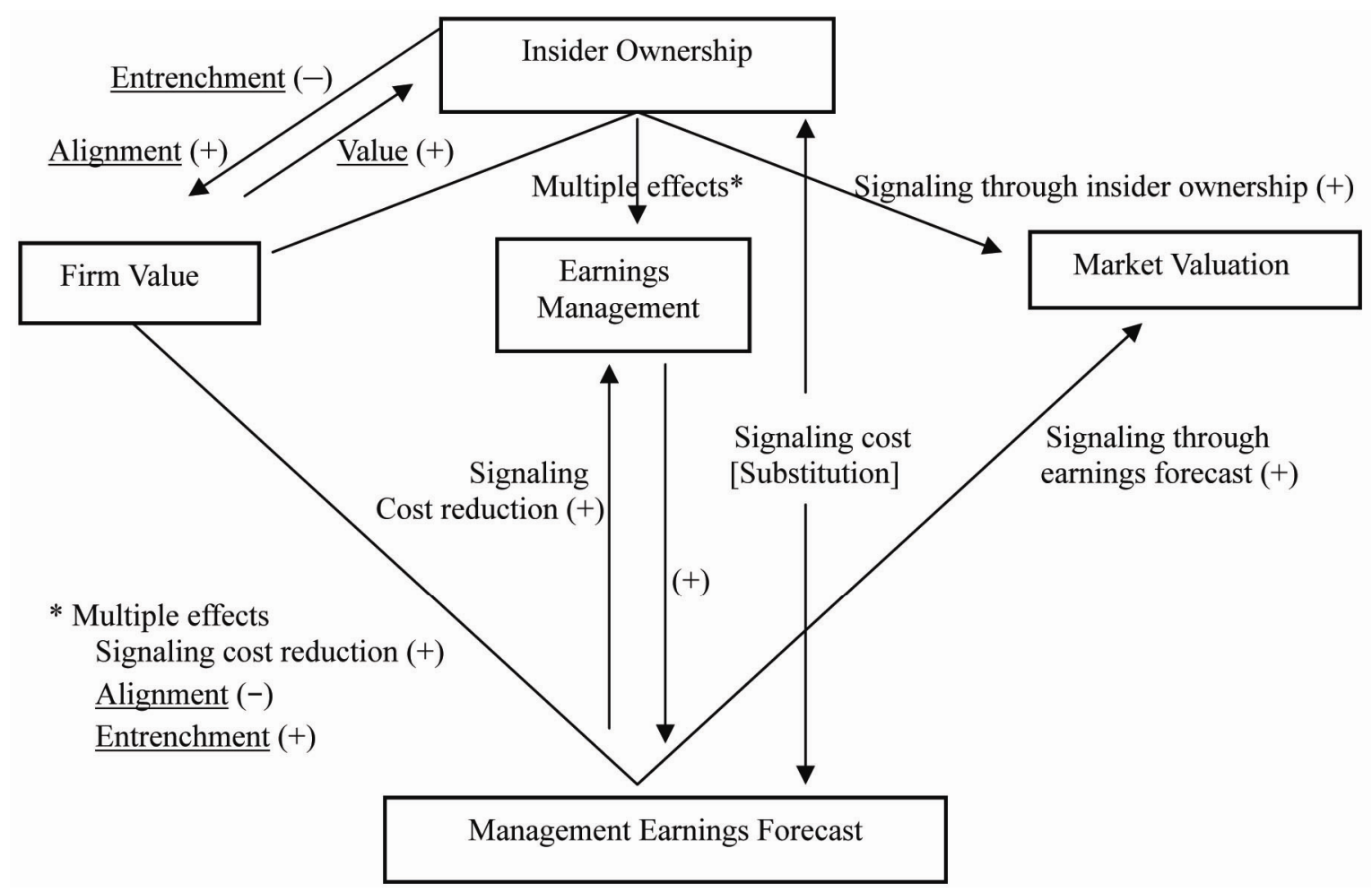

Figure 1. Comprehensive Picture of Simultaneous Signaling, Insider Ownership and Earnings Management Note: Underlined effects are non-signaling effects. 